\title{
ORIGINAL ARTICLE \\ Cimetière du Père-Lachaise. Bats and vampires in French Romanticism
}

\author{
Jens Rydell ${ }^{1, *}$, Johan Eklöf ${ }^{2}$, Marco Riccucci ${ }^{3}$
}

\begin{abstract}
${ }^{1}$ Department of Biology, Lund University, S-22362 Lund, Sweden.

2 Ord och Natur, Krokdalsvägen 88, S-51734 Bollebygd, Sweden.

${ }^{3}$ Museum of Natural History of the University of Florence, I-51025 Florence, Italy.
\end{abstract}

*Corresponding author e-mail: jens.rydell@telia.com

DOI: https://doi.org/10.14709/ BarbJ.11.1.2018.10

Keywords: France, funeral art, iconography, Paris, symbolism

received: July, 8th 2018 accepted: September, 8th 2018

\begin{abstract}
The bats' elusive life style and unusual appearance have always stimulated peoples' imagination, perhaps more so than any other animal. Since medieval times the church has associated bats with the Devil as well as death, darkness and the underground, and, not surprisingly, bats have obtained a given place in folklore, art and fiction. In this paper, we present a remarkable display of bats in Cimetière du Père-Lachaise (the Père Lachaise cemetery) in Paris. The bats are symbolic and occur on vaults from the Romantic period (1820-1850), a passage of European history when bats were quite popular ingredients in artwork and literature, particularly in France. Most of the bat sculptures in Père Lachaise are quite realistic and apparently without any intent to invoke fear or send evil messages. They are typically displayed on the steel gates of the tombs and symbolise death and the long night before the flight to heaven. They often occur in association with an hourglass, a winged skull and/or an ouroboros, icons of the ephemeral nature of life and the eternal cycle of life and death, respectively. We speculate that the bat symbols could also have an apotropaic function, protecting the tomb and its inhabitants from evil forces and/or bad luck. The reputation of bats in Europe has not always been as negative as it is today, and those at Cimetière du Père-Lachaise illustrate its diversity and complexity. The tombs with bats in this cemetery are exclusive and exceptional items of human cultural history and we would strongly appreciate if they would be preserved for future studies and enlightenment.
\end{abstract}

\section{INTRODUCTION}

Bats typically symbolize death, darkness and the underground (Allen 1939, McCracken 1993) and, indeed, have a long and diverse career in religion, myths and folklore in many parts of the world, e.g. in central and southern Europe (Tupinier 1989), Scandinavia (Rääf 1957), tropical Africa (Knappert 1995), East Asia (Volker 1975), America (Benson 1987, Brady \& Coltman 2016) and Australia (Richards et al. 2012). In Europe bats have occurred in religious contexts at least since medieval times, often in the form of devils or demons with bat wings (Rumpler 1996, Lorenzi 2006). Simultaneously and thus contemporary with the beginning of the Great Explorations in the 14th century, slightly more realistic bats appeared in so called bestiaries, which showed strange animals and monsters, some of which were believed to exist in other yet unexplored parts of the world (LeclercqMarx 2016). Bats in the form of fanciful wooden figures were sometimes carved on the underside of the foldable choir seats, the so called Misericordia, in several medieval cathedrals (Remnant 1969). Similar wooden sculptures of bats occasionally decorate other parts of old churches as well (Fig. 1).

The symbolic bats from the Middle Ages made a dramatic transition in the Renaissance (in the 16th century), when Michelangelo Buonarroti, Leonardo da Vinci, Albrecht Dürer and their contemporaries mostly in Italy, used bats in very different and apparently non-religious contexts in architecture, drawings and sculptures (Riccucci \& Rydell 2017). The bat symbols then made another transition during the Baroque (in the 17th and 18th centuries), when they appeared on gravestones and tombs as symbols of death and thus again conveyed a religious message, which persisted throughout the Romantic period (in the 19th century) (Rumpler 2001, 2003, 2005).

In European traditional medicine bats have been used for many purposes at least since the Roman times (Riccucci 2012). Recently, draculin, the glycoprotein found in vampire bat saliva and which prevents blood from coagulating, has become a potentially effective treatment against strokes and heart-attacks (Riccucci 2012), and has greatly influenced the perception of vampires and other bats worldwide. Real or perceived vampires have also been used in forensic science on skeletal remains in Venice (Tsaliki 1999, Nuzzolese et al. 2013). Bats are sometimes the final messengers of death in contemporary fiction, particularly in the context of serious illness (Bernhardsson 2010).

In the literature, bats appeared already in the fables of Aesops more than five hundred years BC (Anon 2018) and, of course, they were also treated in Aristotle's work De Animalibus (On animals) in the 3rd century BC. Bats were quite accurately described in $77 \mathrm{AD}$ by Pliny the Elder in his Naturalis Historia (English translation 1967), 


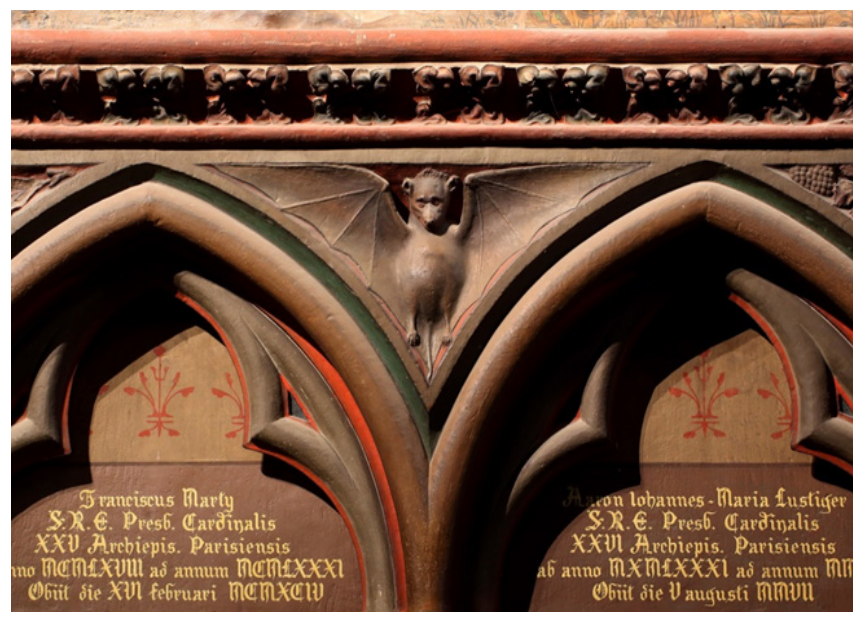

Fig. 1 - A carved wooden bat inside Nôtre Dame de Paris. Photo J. Rydell 2018.

but, nevertheless, they were believed to be birds yet for a long time, even in Historiae Animalium by Gessner (1555), the most important zoological work of the Renaissance. At the very end of that period, finally, a British priest John Swan realized that bats are in fact mammals (Swan 1635), although the credit for this insight is usually given to another Englishman, the biologist John Ray (1693). Bats were finally described and classified scientifically and given Latin names by Linnaeus (1758). Hence the belief that bats are birds remained long after the Renaissance, and this bird/beast dualism has always been an important trade mark of the bats in religion, art and literature (Leclercq-Marx 2016). In the 19th century, vampire tales and artwork became very popular in Europe, and this interest still remains (Guiley 2005, Melton 2011).

The poor reputation of bats prevailing in many countries at present, recently enhanced by exaggerated reports on deadly virus infections believed to be transmitted to humans by bats (Tuttle 2018), results in fear of these animals, and this may destroy the effects of decades of dedicated conservation work by scientists and others (López-Baucells et al. 2018). However, as we shall see, the reputation of bats in Europe has not always been negative. In this note, we present a remarkable display of bat symbols from French Romanticism. It provides a different view and highlights that human perception of bats has a long and complex history.

\section{THE SETTING}

Cimetière du Père-Lachaise, in the middle of Paris, was founded by Napoleon Bonaparte in 1804 and is still used for its original purpose. About a million Paris residents have been buried there, on top of each other, and there are many more in the columbarium, which holds the remains of those who were cremated. The tombs of many cultural celebrities can be found in Père Lachaise, including Maria Callas, Fryderyk Chopin, Gioacchino Rossini, Edit Piaf, Oscar Wilde, Gustave Doré, Molière and many others (Keister 2013). The place is large enough ( $44 \mathrm{ha}$ ) to be a green and quiet oasis in the middle of the capital, and it is functionally also a nature reserve or park. It attracts about 3.5 million visitors per year, locals as well as tourists, photographers and bird watchers (Fonseca et al. 2015).

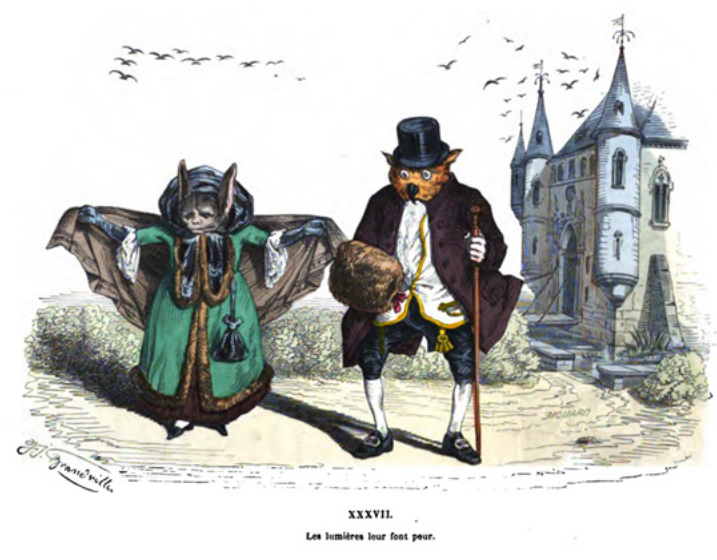

Fig. 2 - Les lumières leur font peur (The lights scare them). Plate XXXVII in Les Metamorphoses du jour (Grandville 1829).

The cemetery is also home to bats of a sort rarely seen in other places. In general, bat symbols are not common in cemeteries, but Père Lachaise is unique in this respect, as bat icons are rather frequent and diverse, occurring in several different designs.

\section{BATS IN FRENCH ROMANTIC LITERATURE}

After the Middle Ages, bats turned up in French literature notably during the 17th century in Fables de La Fontaine (the Fables of La Fontaine), first published in 12 volumes between 1668 and 1694. Bats are essential figures in La Chauve-souris et les deux Belettes and La Chauve-souris, le Buisson et le Canard (The Bat and the two Weasels and The Bat, the Bush and the Duck, respectively; English translation 1884). Later, during the Romantic period, and contemporary with the construction of the vaults in the Cimetière du Père-Lachaise, the main theme of this paper, bats became quite popular figures among French writers and artists, apparently more so than in other European countries. The following account is based partly on the review by Tupinier (1989).

Bats were depicted several times in the beautiful caricatures of J.J. Grandville, e.g. in Les Metamorphoses du jour (Metamorphoses of today) published in 1829 (Fig. 2), Scènes de la vie Privée et Publiques des Animaux (Scenes from the Private and Public life of Animals; 1842) and of course, in his illustrations of Fables de La Fontaine (Lafontaine \& Grandville 1868).

Bats also became important figures in the poetry of Charles Baudelaire (1857), including Les Fleurs du mal (Flowers of evil), one of the most important collections of poems of all time. In this work, the bat belongs to the dark, wet and most depressing of scenes:

Quand le ciel bas et lourd pèse comme un couvercle

Sur l'esprit gémissant en proie aux longs ennuis,

Et que de l'horizon embrassant tout le cercle

II nous verse un jour noir plus triste que les nuits;

Quand la terre est changée en un cachot humide, Où l'Espérance, comme une chauve-souris, S'en va battant les murs de son aile timide 
Et se cognant la tête à des plafonds pourris;

Quand la pluie étalant ses immenses traînées

D'une vaste prison imite les barreaux,

Et qu'un peuple muet d'infâmes araignées

Vient tendre ses filets au fond de nos cerveaux,

Des cloches tout à coup sautent avec furie Et lancent vers le ciel un affreux hurlement, Ainsi que des esprits errants et sans patrie Qui se mettent à geindre opiniâtrement.

- Et de longs corbillards, sans tambours ni musique, Défilent lentement dans mon âme; l'Espoir, Vaincu, pleure, et l'Angoisse atroce, despotique, Sur mon crâne incliné plante son drapeau noir.

Spleen - Charles Baudelaire (1857)

During the Renaissance the bats were associated with Melancholia, one of the four temperaments, and consequently also with an excess of black bile, the melancholy fluid, which was believed to be excreted by the spleen (Eisler 1991). This explains the title of the previous poem.

In Les Fleurs du mal Budelaire also used the vampire, albeit as a metaphore, in other poems - Le Vampire (The Vampire) and Les Métamorphoses du vampire (Metamorphoses of a Vampire):

Toi qui, comme un coup de couteau, Dans mon coeur plaintif es entrée; Toi qui, forte comme un troupeau De démons, vins, folle et parée,

De mon esprit humilié Faire ton lit et ton domaine; - Infâme à qui je suis lié Comme le forçat à la chaîne,

Comme au jeu le joueur têtu, Comme à la bouteille l'ivrogne, Comme aux vermines la charogne

- Maudite, maudite sois-tu!

J'ai prié le glaive rapide De conquérir ma liberté, Et j'ai dit au poison perfide De secourir ma lâcheté.

Hélas! le poison et le glaive M'ont pris en dédain et m'ont dit: "Tu n'es pas digne qu'on t'enlève À ton esclavage maudit,

Imbécile! - de son empire Si nos efforts te délivraient, Tes baisers ressusciteraient Le cadavre de ton vampire!

Le Vampire - Charles Baudelaire (1857)

This piece was part of a European "vampire boom" in the 19th century (Praz 1951, Twitchell 1981), which also included, for example, the novel Le Vampire (The
Return of Lord Ruthven) by Alexander Dumas, first performed in theatre in 1851 and later published in his collected plays (Dumas 1865). In the early vampire stories, such as those about Lord Ruthven/Lord Byron (Polidori 1819), the vampires had nothing to do with bats, but the two were merged shortly afterwards in Pepopukin in Corsica (Young 1826). Suddenly, vampires got wings and could fly. They had become bats and hence legitimate features of this paper.

The French poet Robert de Montesquiou (1893) also used bats in his works, and even published a collection of poems under the title Les Chauves-souris (The Bats). This collection included Les silenciaires (The quiet People), illustrating his fascination over the perceived silence of bats:

O Chauves-souris!
Guepes
Des nuits,
Crepes
D'ennuis
O chauves-souris!
Malsains
Essaims
Valeurs
Pris
Dans les Brises,
Filez,
Frôlez,
Volez,
O mes soeurs
Grises!
Guepes
Des nuits
Tournoiements,
Frôlements,
Sans nuls bruits,
Guepes
Des nuits!
O Chauves-souris
Malsains
Essaims
Valeurs
Pris
Dans les
Brises,
Filez,
Frôlez, Volez
O mes soeurs
Grises!
Crêpes
D'ennuis!
Déroulés,
Envolés
Desprits
couleurs, sans cris,
Crepes
D'ennis

Les silenciaires - Robert de Montesquiou (1893) 
Bats flutter by here and there in other Romantic classics as well. For example, they are ephemeral but quite essential ingredients in the novels Nôtre Dame de Paris (The Hunch-back of Nôtre Dame) by Victor Hugo (1831) and in Flaubert's (1862) Salammboô (Salambô). In the latter, bats appear in thousands, darkening the evening sky above the besieged Cartago.

\section{THE BATS OF CIMETIÈRE DU PÈRE-LACHAISE}

Most of the bats of the Cimetière du Père-Lachaise consist of forged sculptures that are parts of the steel-gates on front of the chapel-like tombs or vaults (Fig. 3). They are usually about twice the natural size of real bats and are consistently displayed with spread wings. They were made between ca. 1820 and 1850, according to the inscriptions of the tombs, i.e. during the height of the Romantic period. The bat symbols in some cases occur in pairs or triplets above or beside each other on the gates. Some of them have long narrow wings, reminiscent of noctules Nyctalus noctula, or, in some cases, serotines Eptesicus serotinus (Fig. 4), while others have broader wings and larger ears, and are more like mouse-eared bats Myotis spp. or even long-eared bats Plecotus spp. (Fig. 5). However, the similarity to real bat species is presumably a coincidence.

The tomb bats are quite realistic and their faces are totally without ugly or evil expressions, and, in fact, are quite reminiscent of the wooden bat in the

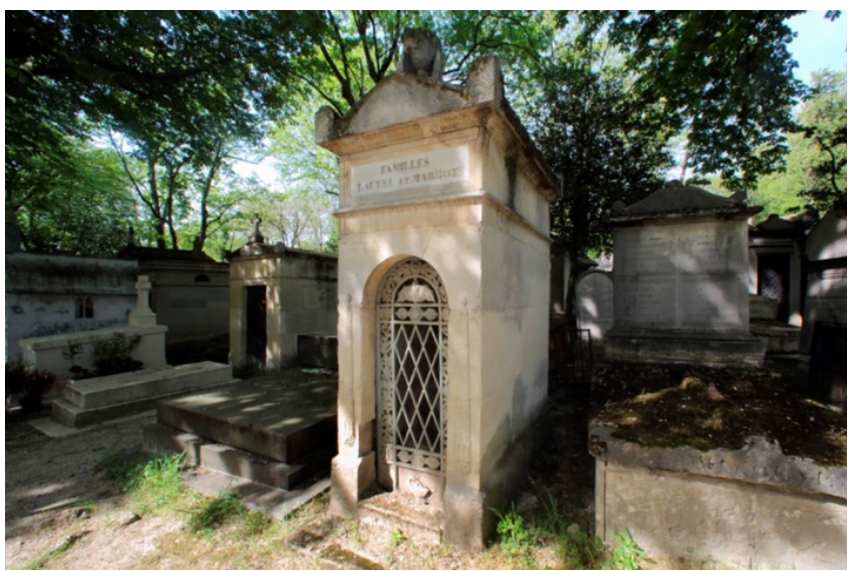

Fig. 3 - A typical vault with the steel gate showing a symbolic bat on top. Père Lachaise cemetery. Photo J. Rydell 2018.

Nôtre Dame (Fig. 1). The similarity can, of course, be a coincidence, although it seems likely that the wooden bat in the church was there long before the steel gates were made, and therefore could have been used as a model. The proportions of the bats are reasonably correct and, in most cases, they show the right number of fingers located in the correct place, as well as realistic ears and tail membranes. The bats shown in Fig. $5 a$ and $5 b$ are the main exceptions, as they have fingers in the wrong place. Incidentally, this also applies to one pair of fingers of the Nôtre Dame bat (Fig. 1).

There are supposed to be 14 bat-gates with $30-40$ bats in total in the cemetery (Atlas Obscura 2018). In some cases, the same type of bat symbol appears on
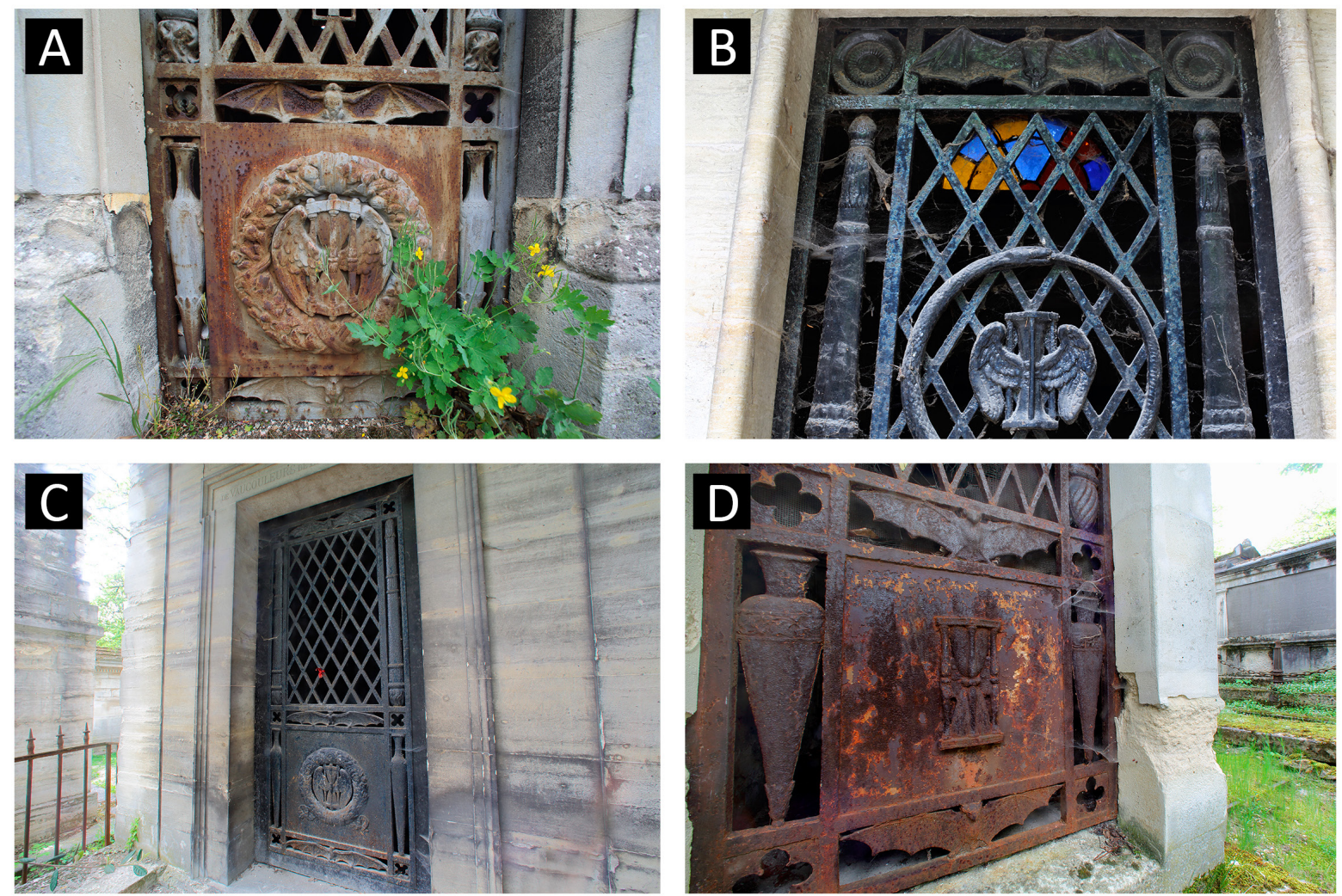

Fig. 4 - Four examples of tomb bats associated with an hourglass. In three of them (a-c) the glass connects a pair of bird wings. In (b) the hourglass is also surrounded by an ouroboros, a symbolic snake biting its tail. Père Lachaise cemetery. Photo J. Rydell 2018. 

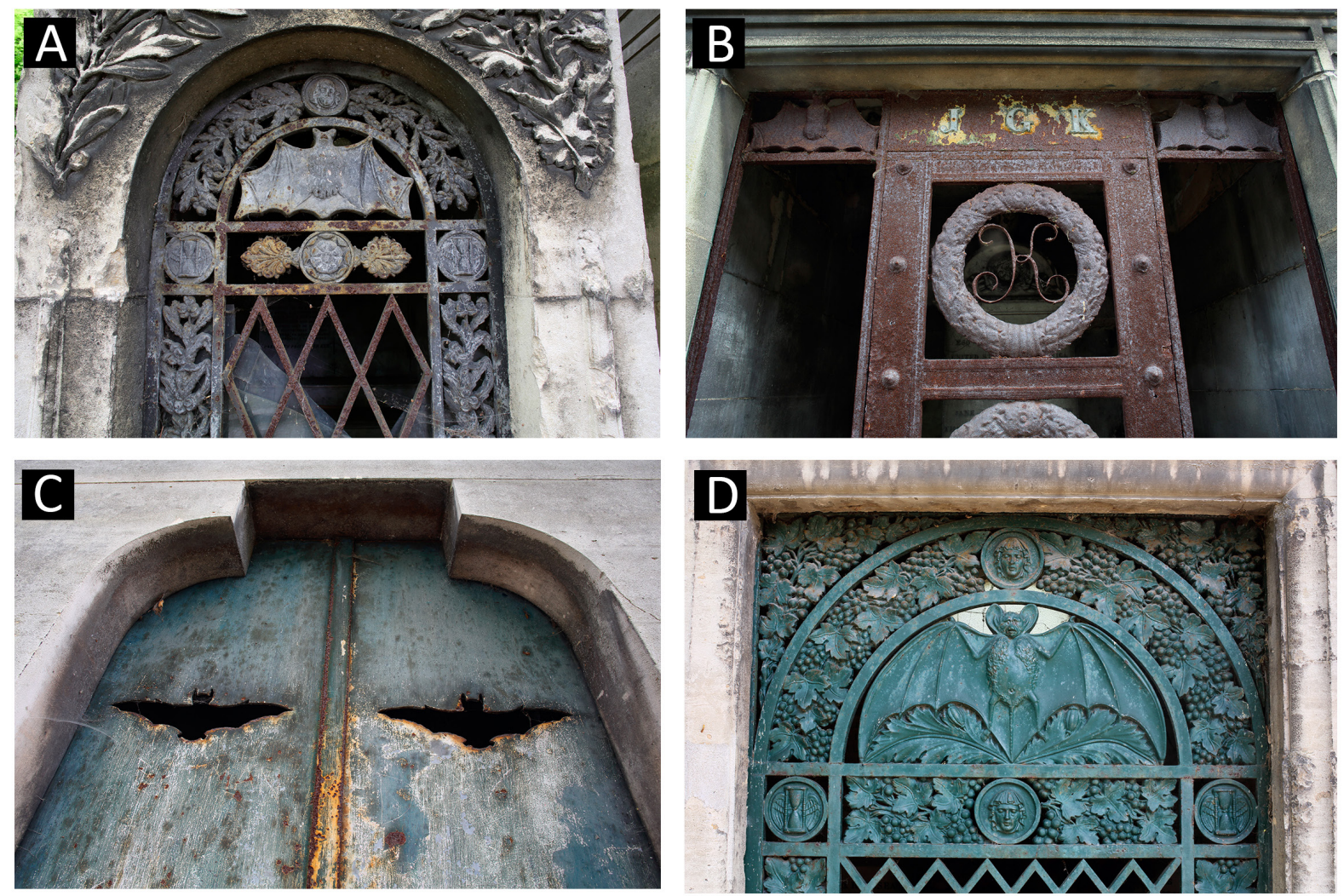

Fig. 5 - Four unusual examples of tomb bats, two of them (c) and (d) are probably unique. Père Lachaise cemetery. Photo J. Rydell 2018.
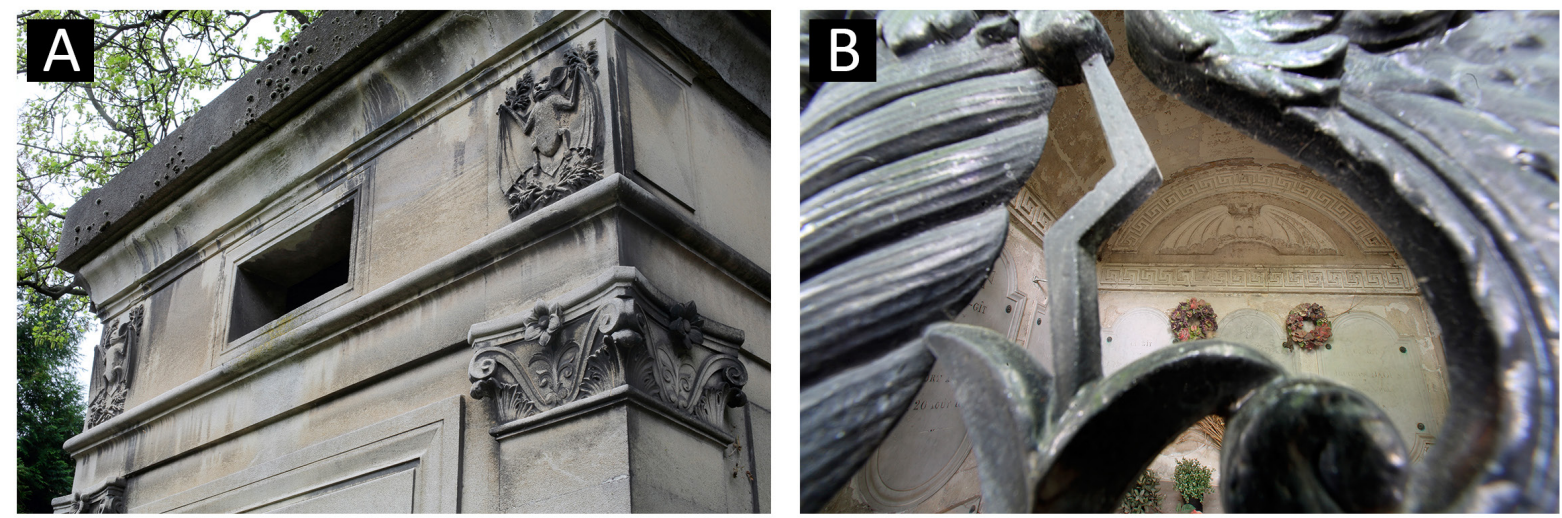

Fig. 6 - Carved bats on the outer (a) and inner (b) walls of tombs, the latter seen through the steel gate. Père Lachaise cemetery. Photo J. Rydell 2018.
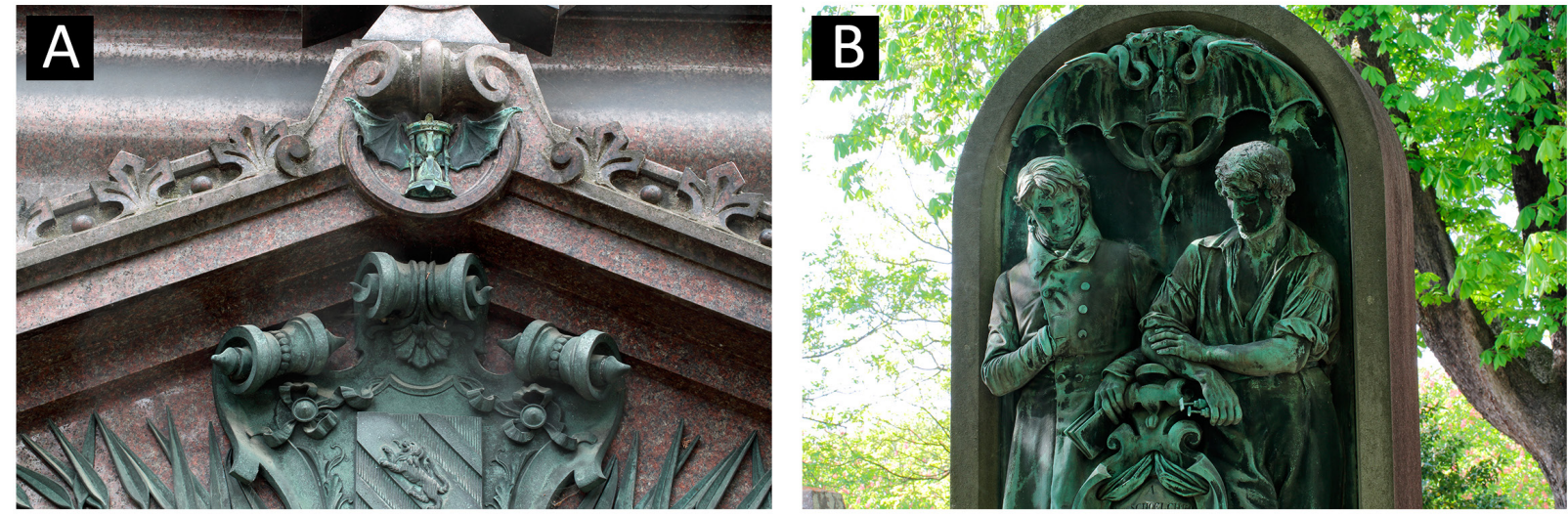

Fig. 7 - Hourglasses with pairs of bat wings. These icons are made in bronze. Père Lachaise cemetery. Photo J. Rydell 2018. 


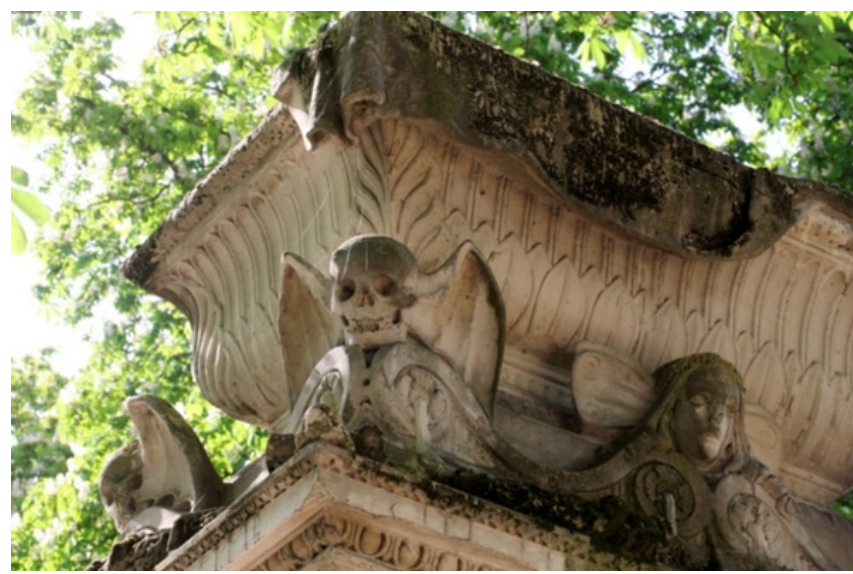

Fig. 8. -Winged skulls on the upper corners of a vault, all carved in stone. Père Lachaise cemetery. Photo J. Rydell 2018.

different gates but there are also bats that seem to be unique (Fig. 5). Clearly, several artists have been involved in the design of the gates and the bats. In addition to the steel bats on the gates, there are a few examples of carved (in stone) bats decorating either the outer or the inner walls of the tombs, but as far as we could see, they are rare and there is no consistent pattern among them (Fig. 6).

Hourglasses are common symbols on the steel gates and, indeed, accompany many of the bats (Fig. 4). They often connect a pair of bird- or bat-wings (Fig. 3a-c) and in some cases the hourglass and the bats occur in association with an ouroboros, a snake forming a circle, while biting its tail (Fig. 4b). There are also a few cases where an hourglass holding a pair of bat wings is the main figure of the tomb (Fig. 7), and the entire figures are then made of bronze rather than steel. In addition, there is at least one case where four skulls with bat wings carved in stone are displayed in the upper corners of a vault (Fig. 8).

\section{DISCUSSION}

Bat was called nukteris in Greek and vespertilio by the Romans, in both cases referring to the night (Nycteris is now the generic name of the slit-faced bats and Vespertilio is the name of the parti-coloured bats; Ferber 2007, Tommasi 2011). The bats' apparent fear of light and their elusive and nocturnal habits (Rydell \& Speakman 1995) have often evoked negative images among humans, and this applies even today. According to the Bible, for example, the bat, being neither bird nor beast, is associated with darkness, and it is also an explicitly unclean creature which should not be eaten or even touched (Leviticus 11:147 , about clean and unclean animals).

This view dominated people's perception of bats from the medieval times in Europe. The association with the underground and the Devil was established in early literature, including the first part Inferno (Hell) of Dante Alighieri's Comedia (later renamed Divina Commedia), written in 1317. It is illustrated in many church frescos and paintings with devils and demons equipped with bat wings and sometimes also bat-ears and sharp teeth (Rumpler 1996, Lorenzi 2006). The association with the Devil has been maintained by the church and obviously has had a strong influence with important negative consequences for bats.

However, the bats of Cimetière du Père-Lachaise, particularly their realistic faces, are more like the wooden bat in the Nôtre Dame (Fig. 1) and also reminiscent of some of the misericords that can be seen in other cathedrals in Europe, which originated in the Middle Ages (Remnant 1969). Similar bat symbols also occur on graves in other places in France, e.g. in Cimetière des Péjoces in Dijon (Chabot 2009, p. 167), but are by no means common.

Bats were popular items in the Romantic literature and artwork. On tombs they symbolise aspects of life and death. The hourglass holding pairs of bator bird-wings, or sometimes (in other places) one wing of each (Rumpler 2003), appeared on graves and tombstones in Europe during the Baroque (17th and 18th century) and was also used later during the Romantic period (Rumpler 2005). The hourglass was sometimes replaced by a winged skull, and both types are found in the Père Lachaise cemetery, although not as frequently as the steel bats. The hourglass, with or without the metaphoric wings, symbolises the ephemeral nature of life, while the associated ouroboros is an ancient symbol of eternity or the cyclic nature of life and death. Likewise, the bat icons refer to the darkness of death and the subsequent flight to heaven (Biedermann 1992, Werness 2004, Chabot 2009).

It remains speculative but quite possible that the bat symbols appearing in the Romantic artwork also had additional properties. Bats are sometimes associated with witchcraft and superstition (Dayrell 1910) and are important creatures in folklore (Kunz 1984, McCracken 1992, Green 1997). Their wings, eyes and particularly the blood were essential ingredients in hell broths and magic drinks, as illustrated in, for example, Shakespeare's The Tragedy of Macbeth, first published in 1623 (Shakespeare 1998). According to Scandinavian folklore, bats have only three drops of blood, but, on the other hand, these rare drops possess magic properties and are extremely useful in many different contexts such as in love affairs, hunting and fishing, and perhaps most importantly, to defeat or stop evil forces and protect against bad luck (Edqvist \& Eklöf 2018).

During the Renaissance, carved and artistically refined bats, sometimes with grotesque faces, symbolised melancholy and also cultural or intellectual darkness or ignorance (Riccucci \& Rydell 2017). However, bat icons probably had apotropaic characteristics as well and could be used for protective purposes. Several such bats are found on the entrances and window sills of Renaissance palaces and churches in Florence (Panofsky 2009). It seems likely that their function was to stop evil forces from entering the building, just as in Scandinavia. This 
habit is also common in China, from where it probably originated (Biederman 1992). Since the Père Lachaise bats usually are placed on top of the door of the vaults, a position also found in China, Florence and Scandinavia, they could also have the same function.

Romanticism turned into Art Nouveau around 1890, a cultural movement where artists looked for new sources of inspiration, especially natural forms such as curved lines of plants and flowers. Bats were still employed however, e.g. as decorations on buildings as well as on ceramics and jewellery. The use of bats for artistic decorations of tombs during the Romantic period may hence be viewed as a transition between the Classicism and the Art Nouveau.

\section{REMARKS}

The cemetery at Père Lachaise is still used as a cemetery and because it is overcrowded with tombs and many of them no longer have living descendants to take care of the facilities, some of the old tombs with bats may be at risk of being taken down to give space to new ones. However, the tombs with bats in Père Lachaise are unique and also remarkable pieces of cultural history. It would be strongly appreciated if they were preserved for future studies and enlightenment. We have deliberately avoided displaying the names and dates that appear on the tombs as well as the residents' history and religion.

\section{ACKNOWLEDGEMENTS}

We acknowledge the inspirational guided tour in the cemetery by the local vampire expert Jacques Sirgent, curator of the Paris Vampire Museum. He also provided several constructive ideas for this paper.

\section{REFERENCES}

ALLEN, G.M. (1939). Bats, biology, behavior and folklore. Harvard University Press, Boston, EEUU, $368 \mathrm{pp}$.

ANON. (2018, September 8th). Aesop's fables. http:// www.aesopfables.com/

ATLAS OBSCURA. (2018, September 8th). The Vampire Museum and occult rituals still practiced in Père Lachaise. Available: https://www.atlasobscura. com/articles/visit-to-the-paris-vampire-museum

BAUDELAIRE, C. (1857). Les Fleurs du mal. PouletMalassis et de Broise, Paris, France, 248 pp.

BENSON, E.P. (1987). Bats in South American iconography. Andean Past, 1(8): 165-190.

BERNHARDSSON, K. (2010). Litterära besvär. Skildringar av sjukdom i samtida svensk prosa. Ellerströms förlag, Lund, Sweden, 416 pp.
BIEDERMAN, H. (1992). Dictionary of symbolism: Cultural icons and the meanings behind them. Facts on Files, New York, EEUU, 465 pp.

BRADY, J.E. \& COLTMAN, J.D. (2016). Bats and the Camazotz: Correcting a century of mistaken identity. Latin American antiquity 27(2): 227-237. https://doi.org/10.7183/1045-6635.27.2.227

CHABOT, A. (2009). Dictionnaire illustré de Symbolique funéraire. La Mémoire Nécropolitaine, Paris \& Memogrames - les éditions de la Mémoire, Bruxelles, Belgium, 623 pp.

DAYRELL, E. (2010). Folk stories from southern Nigeria, West Africa. Kessinger Publishing, LLC. Originally published by Longmans, Green and Company 1910, London, United Kingdom, 176 pp.

DUMAS, A. (1865). Le Vampire. In Théâtre complet de Alex. Dumas. Onzième Série. Michel Levy, Paris, France, $548 \mathrm{pp}$.

EDQVIST, B. \& EKLÖF, J. (2018). Fladdermusen - i en mytisk värld. Bokpro, Bjärnum, Sweden, 176 pp.

EISLER, C. (1991). Dürer's Animals. Smithsonian Institution Press, Washington DC, EEUU, 448 pp.

FERBER, M. (2007). A dictionary of literary symbols, 2nd ed. Cambridge University Press, Cambridge, United Kingdom, 272 pp.

FLAUBERT, G. (1862). Salammbô. Charpentier, Paris. Bibliographie de la France du 6 décembre 1862. Impresion de J. Claye, Paris, France, 475 pp.

FONSECA, A.P., SEABRA, C. \& SILVA, C. (2015). Dark tourism: Concepts, typologies and sites. Journal of Tourism Research \& Hospitality, S2-002. https:// doi.org/10.4172/2324-8807.S2-002

GESSNER, C. (1555). Conradi Gesneri Tigurini medici \& philosophiae professoris in Schola Tigurina. Historiae animalium liber III., qui est de avium natura. Tiguri apud Christoph. Froschoverum, Zürich, Switzerland, 779 pp.

GREEN, T.A. (ed.) 1997. Folklore: An encyclopedia of beliefs, customs, tales, music, and art. ABC-Clio, Santa Barbara, EEUU, 892 pp.

GRANDVILLE, J.J. (1829). Les Metamorphoses du jour. Chez Bulla, Paris, France, 73 hand-colored lithographs.

GRANDVILLE, J.J. (1842). Scènes de la vie Privée et Publiques des Animaux. Volum I and II. J. Hetzel et Paulin, Paris, France, pp. 386-390.

GUILEY, R.E. (2005). The encyclopedia of vampires, werewolves, and other monsters. Facts on File, New York, EEUU, 352 pp. 
HUGO, V. (1831). Nôtre-Dame de Paris. 1482. Volume I and II. Charles Gosselin, Paris, France, pp. 404536.

KEISTER, D. (2013). Stories in stone Paris. A fieldguide to Paris cemeteries and their residents. Gibbs Smith Publishers, Electronic version, 244 pp.

KNAPPERT, J. (1995). African mythology: an encyclopedia of myth and legend. Diamond Books, London, United Kingdom, 272 pp.

KUNZ, T.H. (1984). Bat facts and folklore. American Biology Teacher, 46(1): 394-399.

LA FONTAINE, J. DE (1884). The Fables of La Fontaine, translated mainly by R. Thomson. J.C. Nimmo and Bain, London, United Kingdom, 424 pp.

LA FONTAINE, J. DE \& GRANDVILLE, J.J. (1868). Fables de La Fontaine. Illustrations par Grandville. Garnier Fréres, Libraires-Éditeurs, Paris, France, 667 pp.

LECLERCQ-MARX, J. (2016). Un animal très ambigu. La chauve-souris dans la littérature savante et dans les mentalités médiévales. Yearbook of the International Reynard Society, 28(1): 111-129. https://doi.org/10.1075/rein.28.08lec

LINNAEUS, C. (1758). Caroli Linnæi Systema naturæ per regna tria naturæ, Secundum classes, ordines, genera, species, cum characteribus, differentiis, synonymis, locis. Tomus I. Editio decima, reformata. Salvius, Holmiæ, Sweden, 824 pp.

LÓPEZ-BAUCELLS, A., ROCHA, R. \& FERNANDEZLLAMAZARES, A. (2018). When bats go viral: negative framings in virological research imperil bat conservation. Mammal Review, 48(1): 62-66. https://doi.org/10.1111/mam.12110

LORENZI, L. (2006). Devils in art. Florence, from the Middle Ages to the Renaissance, 2 nd ed. Centro Di Edizione, Florence, Italy, 144 pp.

MCCRACKEN, G.F. (1992). Bats in magic, potions, and medicinal preparations. BATS Magazine, 10(3): 1415.

MCCRACKEN, G.F. (1993). Bats and the Netherworld. BATS Magazine, 11(2):16-17.

MELTON, J.G. (2011). The Vampire book. The encyclopedia of the undead, 3rd ed. Visible Ink Press, Canton, China, 909 pp.

MONTESQUIOU, R. DE. (1893). Les Chauves-Souris. G. Richard, Paris, France, 495 pp.

NUZZOLESE, E. \& BORRINI, M. (2010). Forensic approach to an archaeological casework of "Vampire" skeletal remains in Venice: Odontological and anthropological prospectus. Journal of Forensic Science, 55(6): 1634-1637. https://doi. org/10.1111/j.1556-4029.2010.01525.x
PANOFSKY, E. (2009). Studi di iconologia. I temi umanistici nell'arte del Rinascimento. Einaudi, Milano, Italy, $388 \mathrm{pp}$.

PLINY THE ELDER. (1967). Naturalis historia. English translation by $\mathrm{H}$. Rackham. Harvard University Press, Boston, EEUU, $580 \mathrm{pp}$.

POLIDORI, J.W. (1819). The Vampyre; A tale. Sherwood, Neely, and Jones, London, United Kingdom, 84 pp.

PRAZ, M. (1951). The Romantic agony, 2nd ed. Oxford University Press, London, United Kingdom, 502 pp.

RÄ̈̈F, L.E. (1957). Svenska skrock och signerier. Almqvist \& Wiksell, Stockholm, Sweden, 445 pp.

RAY, J. (1693). Synopsis methodica animalium quadrupedum et serpentini generis. Impensis $\mathrm{S}$. Smith \& B. Walford, London, United Kingdom, 336 pp.

REMNANT, G.L. (1969). Misericords in Great Britain. Oxford University Press, Oxford, United Kingdom, $221 \mathrm{pp}$.

RICCUCCI, M. (2012). Bats as materia medica: an ethnomedical review and implications for conservation. Vespertilio, 16(1):249-270.

RICCUCCI, M. \& RYDELL, J. (2017). Bats in the Florentine Renaissance: from darkness to enlightenment. Lynx, 48(1): 165-182.

RICHARDS, G., HALL, L. \& PARISH, S. (2012). A natural history of Australian bats: Working the night shift. CSIRO Publishing, Collingwood, Australia, 192 pp.

RUMPLER, G. (1996). Die Fledermaus in der mittelalterlischen Bauplastik. Nyctalus, 6(1): 6570 .

RUMPLER, G. (2001). Die Fledermaus in der Bauplastik des 19. und 20. Jahrhunderts. Nyctalus, 7(1): 572588.

RUMPLER, G. (2003). Die Fledermaus in der Bauplastik des 17. und 18. Jahrhunderts. Nyctalus, 8(1): 444455.

RUMPLER, G. (2005). Die Fledermaus in der Plastik des Barock und der Neuzeit - Neue Erkenntnisse und weitere Beispiele. Nyctalus, 10(1): 9-25.

RYDELL, J. \& SPEAKMAN, J.R. (1995). Evolution of nocturnality in bats: Potential competitors and predators during their early history. Biological Journal of the Linnean Society, 54(2): 183-191. https://doi.org/10.1111/j.1095-8312.1995. tb01031.x

SHAKESPEARE, W. (1998). The tragedy of Macbeth. Oxford University Press, Oxford, United Kingdom, $272 \mathrm{pp}$. 
SWAN, J. (1635). Speculum Mundi, or, a Glasse representing the face of the world shewing both that it did begin, and must also end, the manner how, and the time when, being largely examined. Printers to the Universitie of Cambridge, Cambridge, United Kingdom, 504 pp.

TOMMASI, C. (2011). Bats in Greco-Roman antiquity. The literary creation of "demon bats". BATS Magazine, 29(1): 6-8.

TSALIKI, A. (1999). Funerary and biological archaeologypalaeopathology. Journal of Paleopathology, 11(1): 116-117.

TUPINIER, D. (1989). La chauve-souris et I'homme. L'Harmattan, Paris, France, 218 pp.

TUTTLE, M.D. (2018). Fear of bats and its consequences. Journal of Bat Research and Conservation, 10(1): 6669. https://doi.org/10.14709/BarbJ.10.1.2017.09
TWITCHELL, J.B. (1981). The living dead. A study of the vampire in Romantic literature. Duke University Press, Durham, United Kingdom, 219 pp.

VOLKER, T. (1975). The animal in Far Eastern art and especially in the art of the Japanese netsuke with references to Chinese origins, traditions, legends, and art. Brill, Leiden, Netherlands, 190 pp.

WERNESS, H.B. (2004). The Continuum encyclopedia of animal symbolism in art. Continuum, New York, EEUU, 476 pp.

YOUNG, A. (1826). Pepopukin in Corsica, pp. 45-71, In: The Stanley tales, original and select. Chiefly collected by the Late Ambrose Marten, of Stanley Priory, Teesdale. W. Morgan, London, United Kingdom, 334 pp. 